\title{
ANALISIS PENGARUH ASSETS DAN MANAJEMEN INVENTORY TERHADAP MANAJEMEN LABA PADA PERUSAHAAN MAKANAN DAN MINUMAN YANG LISTING DI BURSA EFEK INDONESIA 2010 - 2012
}

\author{
Windasari Rachmawati \\ Vinsensia Retno Widi Wisayang \\ Universitas Semarang \\ windasarirachmawati@yahoo.com \\ retnovinsensia@yahoo.com
}

\begin{abstract}
This research aims to learn the effect of the values of the quick ratio, turnover asset, return on assets, and inventory turnover toward net profit before taxes in the food and beverage industry in Jakarta Stock Exchange (Indonesia) in 2010-2012. The approach used is qualitative approach with multiple regression. Based on the analysis described previously, it can be concluded that from the independent variable of turnover asset, return on assets and inventory turnover partially have positive and significant impact on Ebit or profit. This proves the previous studies that management of assets and inventory affect earnings before tax (EBIT). From the analysis ATR, ROA and ITO have effects on Ebit or profits. So, the employers of company are advised to keep ATR, ROA and ITR to remain high in order to get higher profits.
\end{abstract}

Keywords: assets, stocks, earnings before tax

\section{PENDAHULUAN}

Pada saat sekarang ini yang selalu menjadi berita hangat dalam kaitannya dengan pasar modal yaitu pada laporan keuangannya yang tidak efisien dan relevan pada transparansi laporan keuangannya. Pesatnya perkembangan tekhnologi, maka pasar modal pada masa sekarang ini transparansi laporan keuangan pada perusahaan - perusahaan yang sahamnya diperdaganggkan di bursa efek. Munculnya skandal besar pada awal tahun antara lain Xerox 2000, enron 2001, dan world com 2002 menyebabkan berkurangnya kepercayaan investor terhadap keakuratan informasi keuangan yang diterbitkan perusahaan. Manajer menggunakan manajemen laba (earning management) untuk memanipulasi informasi akuntansi untuk mencapai beberapa tujuan.Manajemen laba merupakan salah satu alat yang digunakan untuk memanipulasi informasi akuntansi. Karena mendapatkan keuntungan melalui perdagangan dipasar modal. Manajer perusahaan kadang - kadang memanipulasi laba sebelum tanggal diterbitkannya IPO (initial public offering), management buyout, merger dan akusisi, dan penawaran lainnya.

Menurut IAI (2009) tujuan laporan keuangan adalah menyediakan informasi yang mengenai posisi keuangan, kinerja perusahaan, serta perubahan posisi keuangan yang bermanfaat bagi sejumlah besar pemakai dalam pengambilan 
keputusan ekonomi.Oleh karena itu, laporan yang berkualitas, yang terbebas dari rekayasa dan mengungkapkan informasi sesuai dengan fakta yang sebenarnya menjadi kepentingan banyak pihak. Laporan keuangan merupakan bentuk pertanggungjawaban manajemen perusahaan kepada pihak-pihak yang berkepentingan, seperti pemegang saham, investor, kreditor, pemerintah, masyarakat maupun pihak-pihak lainnya.

Di Indonesia ada dua bentuk perbedaan perlakuan penghitungan pos rekening laba rugi (tjahjono, 1997) pertama perbedaan tetap adalah transaksi - transaksi pendapatan dan biaya tertentu yang boleh diakui akuntansi, tetapi tidak boleh diakui oleh pajak (peraturan pajak) atau sebaliknya. Kedua perbedaan waktu adalah perbedaan pengakuan pendapatan atau biaya untuk perhitungan laba.

Berdasarkan hasil penelitian leuz et.al (2003) terungkap bahwa Indonesia sebagai negara yang mempunyai tingkat manajemen laba yang tinggi. Hal disebabkan oleh rendahnya legal enforcement dan proteksi terhadap investor.

Teori akuntansi positif (contracting theory) menjelaskan bahwa akuntansi sebagai alat pengawasan dalam pelaksanaan kontrak antara pihak - pihak yang terikat pengelolaan perusahaan.Akuntansi menyediakan informasi yang menjadi basis penentuan keputusan, alokasi sumber daya, kompensasi manajemen dan pengawasan perjanjian utang.

Diduga bahwa terjadi manipulasi laba pada perusahaan kelompok sektor makanan dan minuman yang listing di BEI selama tahun $2010-2012$.

Dipilihnya perusahaan makanan dan minuman sebagai objek penelitian ini dikarenakan perusahaan ini merupakan salah satu perusahaan yang memegangperanan penting dalam kebutuhan konsumen, semakin besar pula persaingan dalam dunia usaha ini. Meskipun kondisi ekonomi di indonesia saat ini tidak terlalu bagus, permintaan pasar akan kebutuhan makanan dan minuman ini tidak terpengaruh sedikitpun

Melihat pentingnya analisis laporan keuangan, khususnya dengan menggunakan analisis rasio keuangan untuk mengetahui kemajuan usaha perusahaan dalam memprediksi laba di masa mendatang maka penulis mengambil sampel perusahaan Makanan dan Minuman yang berkaitan dengan masalah analisis Rasio Asset Turnover, Return On Asset (ROA), Inventory Turnover.

Berdasarkan latar belakang yang sudah diuraikan sebelumnya, maka rumusan masalah dalam penelitian ini adalah:

"Apakah rasio perputaran persediaan (ITR), rasio perputaran total aktiva (ATR), rasio pengembalian atas aktiva (ROA) berpengaruh terhadap laba sebelum pajak (EBIT) pada perusahaan industri makanan dan minuman yang listing di bursa efek Indonesia 2010 - 2012?"

\section{KAJIAN PUSTAKA}

\section{Asset Turn Over Terhadap Manajemen Laba}

Menurut Dyckman et al (1999), "Aktiva adalah manfaat ekonomi yang dapat terealisasi di masa depan yang diperoleh atau diakuisisi oleh entitas tertentu sebagai hasil dari transaksi atau kejadian masa lalu." Sedangkan menurut Warren et al (2005), "Aktiva (asset) adalah sumber daya yang dimilikioleh entitas bisnis atau usaha. Sumber daya ini dapat berbentuk fisik ataupun hak yang mempunyai nilai ekonomis.

Aktiva tetapa adalah aktiva berwujud yang dalam bentuk siap pakai atau dengan dibangun lebih dahulu yang digunakan dalam perusahaan, tidak dimaksud untuk dijual dalam rangka kegiatan normal perusahaan dan mempunyai masa manfaat lebih dari satu tahun.(Ikatan Akuntan Indonesia, 2009).

Asset Turnover menunjukkan kemampuan dana yang tertanam dalam keseluruhan aktiva berputar dalam suatu 
periode tertentu atau kemampuan modal yang diinvestasikan untuk menghasilkan "revenue" (Bambang Riyanto, 2008). Diharapkan Assets Turnover akan semakin naik yang berarti pemakaian aktiva lebih efisien (Syafaruddin Alwi, 1993) . Rasio yang tinggi biasanya menunjukkan manajemen yang baik, (Mamduh M.Hanafi \& Abdul Halim, 2003). Semakin besar menunjukkan semakin efisien penggunaan seluruh aktiva perusahaan dalam meningkatkan penjualan. Hasil penelitian dari Dian Meriewati dan Astuti Yuli Setiani (2005), Epri Ayu Hapsari (2007) yaitu Assets Turnover berpengaruh positif signifikan terhadap pertumbuhan laba. Berdasarkan teori dan hasil penelitian tersebut diajukan hipotesis pertama sebagai berikut:

$\mathrm{H} 1=$ Assets Turnover berpengaruh positif terhadap manajemen laba

\section{Return On Asset Terhadap Manajemen Laba}

Menurut Prastowo dan Julianty (2008) return on asset (ROA) digunakan untuk mengukur kemampuan perusahaan dalam memanfaatkan assetnya untuk memperoleh laba. Rasio ini mengukur tingkat pengembalian investasi yang telah dilakukan perusahaan dengan menggunakan seluruh dana (asset) yang dimilikinya. Return on Asset (ROA) digunakan untuk mengukur kemampuan manajemen dalam memperoleh keuntungan (laba) secara keseluruhan. ROA untuk mengukur efektivitas perusahaan dalam menghasilkan laba melalui pengoperasian aktiva yang dimiliki. Semakin besar ROA yang dimiliki oleh perusahaan maka semakin efisien penggunaan aktiva sehingga akan memperbesar laba. Laba yang besar akan menarik investor karena perusahaan memiliki tingkat pengembalian yang semakin tinggi. Dengan kata lain, semakin tinggi rasio ini maka semakin baik produktivitas asset dalam memperoleh keuntungan bersih. Hal ini selanjutnya akan meningkatkan daya tarik perusahaan kepada investor. Peningkatan daya tarik perusahaan menjadikan perusahaan tersebut makin diminati investor, karena tingkat pengembalian akan semakin besar. Semakin tinggi rasio yang diperoleh maka semakin efisien manajemen asset perusahaan. Penelitian Widyastuti (2009) menemukan hasil bahwa variabel profitabilitas yang diukur dengan return on asset (ROA) berpengaruh positif pada manajemen laba. Penelitian Dewi dan prasentiono (2012) juga menemukan pengaruh positif dari profitabilitas.

Semakin besar perubahan ROA menunjukkan semakin besar fluktuasi kemampuan manajemen dalam menghasilkan laba. Hal ini mempengaruhi investor dalam memprediksi laba dan memprediksi risiko dalam investasi sehingga memberikan dampak pada kepercayaan investor terhadap perusahaan. Sehubungan dengan itu, manajemen termotivasi untuk melakukan manajemen laba, agar laba yang dilaporkan tidak berfluktuatif sehingga dapat meningkatkan kepercayaan investor. (Budiasih, 2009). Berdasarkan teori dan hasil penelitian tersebut diajukan hipotesis pertama sebagai berikut:

$\mathrm{H} 2=$ Return On Assets berpengaruh positif terhadap manajemen laba

\section{Ratio Perputaran Persediaan Terhadap Manajemen Laba}

Persediaan merupakan aktiva yang harus dikelola dengan baik, kesalahan dalam pengelolaan akan mengakibatkan komponen aktiva lain menjadi tidak optimal, bahkan bisa mengakibatkan kerugian. Pengelolaan dalam hal memanajemen perputaran persediaan bisa sangat menentukan dalam manajemen kelanjutan aktivitas perusahaan. Menurut Munawir (dalam Nina Sufiana dan Ketut Purnawati, 2013) menyatakan bahwa semakin tinggi tingkat perputaran persediaan akan memperkecil resiko terhadap kerugian yang disebabkan karena penurunan harga atau karena perubahan selera konsumen, disamping itu akan menghemat ongkos 
penyimpanan dan pemeliharaan terhadap persediaan tersebut.

Penelitian yang mendukung teori ini adalah Irman Deni (2014) yang menyatakan perputaran persediaan berpengaruh positif dan signifikan terhadap profitabilitas. Nina Sufiana dan $\mathrm{Ni}$ Ketut Purnawati (2013), dalam hipotesis penelitiannya membuktikan secara empiris bahwa perputaran persediaan berpengaruh positif terhadap profitabilitas.Dari teori yang telah diungkapkan pada hipotesis yang pertama, bahwa semakin tinggi tingkat perputaran persediaan dapat memperkecil resiko kerugian akibat perubahan harga dan perubahan selera konsumen. Dalam perumusan hipotesis yang kedua juga masih didukung oleh penelitian sebelumnya yang telah dilakukan oleh Irman Deny (2014) dan Nina Sufiana (2013) yang menyatakan bahwa perputaran persediaan berpengaruh positif signifikan terhadap profitabilitas.

H3= Inventory Turn Over berpengaruh positif terhadap manajemen laba

\section{Manajemen Laba \\ Pengertian Manajemen Laba}

Riahi (2006) mendefinisikan manajemen laba adalah suatu kemampuan untuk memanipulasi pilihan-pilihan yang tersedia dan mengambil pilihan yang tepat untuk mendapatkan tingkat laba yang diinginkan. Manajemen laba muncul akibat masalah keagenan yang terjadi, yaitu adanya ketidakselarasan kepentingan antara principal (pemegang saham) dan agent (manajemen perusahaan). $\mathrm{Pi}$ hak prinsipal termotivasi mengadakan kontrak untuk menyejahterahkan dirinya dengan profitabilitas yang selalu meningkat sedangkan agen termotivasi memaksimalkan kebutuhan ekonomi dan psikologisnya, antara lain dalam hal memperoleh pinjaman, investasi, dan kontrak kompensasi. Manajemen laba dapat terjadi karena adanya asimetri informasi, yaitu pihak manajemen perusahaan lebih banyak mengetahui informasi mengenai kinerja perusahaan dan prospek perusahaan di masa mendatang daripada para pemegang saham. Akibatnya manajer perusahaan leluasa untuk melakukan rekayasa laporan keuangan. Laba dapat dikatakan berkualitas tinggi apabila laba yang dilaporkan dapat digunakan oleh pengguna (users) untuk membuat keputusan yang terbaik, yaitu laba yang memiliki karakteristik relevan, reliabel, dan komparabel atau konsisten. Rendahnya kualitas laba akan dapat membuat kesalahan dalam pengambilan keputusan oleh para pengguna.

Menurut Sulistyanto (2008), manajemen laba adalah upaya manajer perusahaan untuk mengintervensi atau mempengaruhi informasi-informasi dalam

laporan keuangan dengan tujuan untuk mengelabui stakeholder yang ingin mengetahui kinerja dan kondisi perusahaan.

Scott (2006) dalam Dewi, (2010) mendefinisikan manajemen laba sebagai pilihan kebijakan akuntansi yang dilakukan manajer untuk tujuan spesifik. Dari definisi tersebut, dapat disimpulkan bahwa manajer mempunyai perilaku opportunistic dalam mengelola perusahaan. Manajer mempunyai kebebasan untuk memilih dan menggunakan alternatif-alternatif yang tersedia untuk menyusun laporan keuangan sehingga laba yang dihasilkan dapat meningkatkan kepercayaan pihak lain, walaupun laba yang dihasilkan tersebut tidak mencerminkan keadaan perusahaan yang sebenarnya.

\section{METODE PENELITIAN}

Penelitian ini dilaksanakan di bursa efek Jakarta (Indonesia) pada perusahaan industri makanan dan minumandi BEl periode tahun 2010 sampai dengan 2012.

Dengan memilih kategori perusahaan makanan dan minuman yang berjumlah 21 perusahaan yang listing di bursa efek indonesia, serta memiliki rasio perputaran perusahaan yang cepat dan efisien.

Kriteria yang digunakan dalam penelitian ini adalah sebagai berikut: (1) Semua 
perusahaan yang terdaftar di Bursa Efek Indonesia pada periode 2010-2012 khusus sektor makanan dan minuman. (2) Semua perusahaann yang menyampaikan Laporan Keuangan dan Annual Report secara berturut turut dari tahun 2010-2012 dan menggunakan mata uang Rupiah. (3) Perusahaan yang memiliki inventory turn over, asset turn over dan return on assets.

Metode pengumpulan data dalam penelitian ini dikumpulkan dengan metode studi pustaka dan dokumentasi. Metode studi pustaka dilakukan dengan mencari data melalui buku, jurnal. Atau artikel ilmiah. Sedangkan metode dokumentasi dilakukan dengan mengumpulkan laporan tahunan perusahaan yang diperlukan. Sedangkan metode analisis data dalam Penelitian ini berupa analisis statistik deskriptif dan uji asumsi klasik. Metode analisis yang digunakan untuk melakukan uji hipotesis adalah analisis regresi. Metode analisis regresi yang dipilih adalah analisis regresi berganda (multiple regression analysis). Hal tersebut dikarenakan dalam penelitian ini terdapat lebih dari satu variabel independen. Sebelum melakukan analisis regresi berganda terlebih dahulu dilakukan uji statistik deskriptif dan uji asumsi klasik.

\section{Asset Turn Over (ATR)}

Rasio perputaran persediaan merupakan rasio antara penjualan bersih terhadap total asset yang digunakan oleh operasional perusahaan. Rasio ini menunjukkan kemampuan aktiva perusahaan dalam menghasilkan total penjualan bersih. Asset turn over menurut widodo (2007) mendefinisikan sebagai rasio yang digunakan untuk mengukur seberapa efisiensinya seluruh aktiva perusahaan digunakan untuk menunjang kegiatan penjualan dengan membandingkan antara penjualan dengan total aktiva. Jika penjualan lebih besar dari total aktiva maka tingkat pengembalian keuntungan atau return yang didapat perusahaan akan tinggi, karena penjualan meningkat mencerminkan keuntungan yang besar bagi perusahaan. Sebaliknya jika total aktiva yang tinggi daripada penjualan, maka return atau tingkat pengembalian keuntungan akan rendah.

Secara matematis rasio perputaran penjualan diformulasikan sebagai berikut: (Brigham, 1983)

\section{Return On Asset (ROA)}

Mengukur kemampuan perusahaan dalam menghasilkan laba bersih berdasarkan tingkat asset tertentu atau rasio yang menunjukkan seberapa mampu perusahaan menggunakan asset yang ada untuk menghasilkan laba atau keuntungan (gumantri, 2011). Rasio profitabilitas (profitability ratio) terdiri dari dua jenis yaitu rasio yang menunjukkan profitabilitas dalam kaitannya dengan penjualan (profitabilitas penjualan) dan rasio yang menunjukkan investasi (profitabilitas investasi).

Menurut Ang (1997) return on asset adalah perbandingan antara laba bersih setelah pajak, terhadap total asset. Jika net income after tax lebih besar dari total asset atau aktiva maka return atau tingkat pengembalian keuntungan tinggi.Karena perusahaan dapat menggunakan asset yang dimiliki dengan baik.Profitabilitas penjualan dirumuskan berdasarkan margin laba kotor dan margin laba bersih (Robert Ang, 1997).

Rasio ini menjelaskan laba berhubungan dengan penjualan dikurangi biaya untuk memproduksi barang yang dijual.Rasio tersebut sebagai pengukur efisiensi operasi perusahaan, serta merupakan indikasi dari penetapan harga produk (Robert Ang, 1997).

Margin laba bersih adalah ukuran profitabilitas perusahaan dari penjualan setelah memperhitungkan semua biaya dan pajak penghasilan.

Dengan mempertimbangkan secara bersama kedua rasio tersebut maka terdapat suatu pandangan, jika margin laba kotor tidak terlalu banyak berubah sepanjang tahun, tetapi margin laba bersih turun dalam periode yang sama, penyebabnya mungkin 


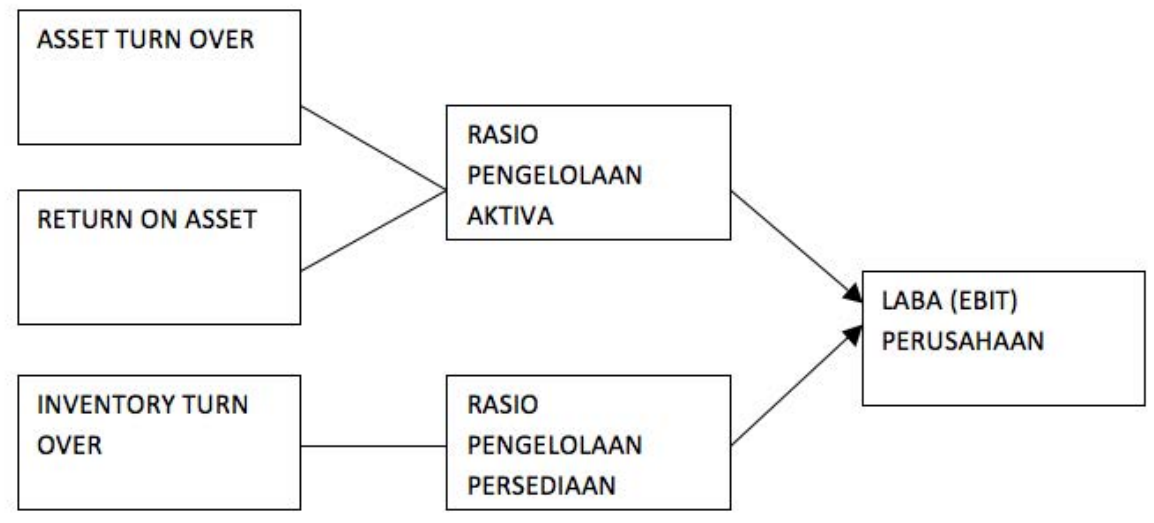

biaya penjualan, umum dan administrasi terlalu tinggi. Jika margin laba kotor turun, biaya untuk memproduksi barang meningkat jika dibandingkan dengan penjualan. Hal ini karena harga lebih rendah atau efisiensi operasi rendah.

Profitabilitas dalam hubungannya dengan investasi, menghubungkan laba dengan investasi. Salah satu pengukurannya adalah tingkat pengembalian investasi (Return on investment - ROI) atau tingkat pengembalian atas aktiva (ROA).

Pengembalian atas total aktiva (ROA) dihitung dengan cara membandingkan laba bersih setelah bunga dan pajak dengan total asset (Kasmir,2011),

\section{Rasio Perputaran Persediaan (ITR)}

Masa perputaran persediaan dapat digunakan untuk melihat apakah terdapat ketidakseimbangan yang bisa saja menunjukkan kelebihan investasi dalam berbagai komponen tertentu persediaan ( home dan wacchowicz: 2009: 217).

Menurut Bambang riyanto (2001: 69) masalah penentuan besarnya investasi atau alokasi modal dalam persediaan mempunyai efek langsung terhadap keuntungan perusahaan.Kesalahan dalam penetapan besaran investasi dalam inventory akan menekan keuntungan perusahaan. Perusahaan makanan dan minuman selalu berhubungan dengan persediaan, karena kegiatan produksinya membutuhkan barang yang di siapkan sepanjang waktu.

\section{Bagan Kerangka Konseptual}

Kerangka konseptual mencerminkan sintesa dan ekstrapolasi dari tinjauan teori dan penelitian terdahulu yang mencerminkan keterkaitan antara variabel yang diteliti dan merupakan tuntutan untuk memecahkan masalah penelitian serta merumuskan hipotesis. Penelitian ini menggunakan tiga variabel dependen yaitu Asset Turn Over (ATR) ,ReturnOn Asset (ROA), Inventory Turn Over (ITR) dan variabel dependen yaitu Manajemen Laba.

Berdasarkan kerangka konseptual yang telah diuraikan, dapat dirumuskan hipotesis sementara sebagai berikut :

$\mathrm{H} 1$ : Terdapat pengaruh rasio perputaran total aktiva (ATR) terhadap laba sebelum pajak (EBIT) perusahaanindustri makanan dan minuman di BEI tahun 2010-2012

$\mathrm{H} 2$ : Terdapat pengaruh rasio pengembalian atas aktiva (ROA) terhadap laba sebelum pajak (EBIT) perusahaan industi makanan dan minuman periode tahun 2010 $-2012$.

H3: Terdapat pengaruh rasio perputaran persediaan (ITR) terhadap laba sebelum pajak (EBIT) perusahaan industry makanan dan minuman di BEI tahun 2010- 2012.

\section{HASIL DAN PEMBAHASAN Uji Normalitas Data}

Uji normalitas bertujuan menguji apakah dalam model regresi, variabel dependen dan variabel independen keduanya mempunyai distribusi normal atau tidak. Model regresi yang baik adalah memiliki distribusi normal 
atau mendekati normal.Untuk mendeteksi normalitas dapat dilakukan dengan uji statistic. Tes statistic yang digunakan antara lain analisis grafik histogram, normal probability plots dan kolmogorov - smirnov test (Imam Ghozali, 2001).

Pada variabel $X 1$ asset turn over signifikansi $(p)$ diperoleh sebesar 0,038 . Dalam hal ini nilai $p>\alpha$ dimana $0,038>$ 0,05 sehingga $\mathrm{H} 1$ diterima dan dapat disimpulkan bahwa data variabel assets turn over berdistribusi normal.

Pada variabel $\mathrm{x} 2$ return on assets signifikansi (p) diperoleh sebesar 0,006. Dalam hal ini nilai $p>a$ dimana $0,006>0,05$ sehingga $\mathrm{H} 2$ diterima dan dapat disimpulkan bahwa data variabel assets turn over berdistribusi normal.

Pada inventory turn over (x3) signifikansi (p) diperoleh sebesar 0,027. Dalam hal ini nilai $p>\alpha$ dimana $0,006>0,05$ sehingga $\mathrm{H} 3$ diterima dan dapat disimpulkan bahwa data variabel inventory turn over berdistribusi normal.

\section{Uji Normalitas Variabel Ebit atau Laba}

(Y)

Hasil uji normalitas variabel laba atau Ebit

(Y) dengan menggunakan uji KolmogorovSmirnov.

Pada variabel manajemen laba $(\mathrm{Y})$ signifikansi $(p)$ diperoleh sebesar 0,027. Dalam hal ini nilai $p>\alpha$ dimana 0,006 > 0,05 sehingga $\mathrm{HO}$ diterima dan dapat disimpulkan bahwa data variabel Ebit atau Laba berdistribusi normal.

\section{Uji Multikolonieritas}

Pengujian asumsi kedua adalah uji multikolonieritas (multicolonierity) antara variabel - variabel independen yang masuk ke dalam model. Metode untuk mendiagnose adanya multikolonearity dilakukan dengan diduganya korelasi $(r$ ) diatas 0,70 (singgih santoso, 1999); dan ketika korelasi derajat nol juga tinggi, tetapi tak satupun atau sangat sedikit koefisien regresi parsial yang secara individu signifikan secara statistic atas dasar pengujian $t$ yang konvensional (Gujarati, 1995). Disamping itu juga dapat digunakan uji variance inflation factor (VIF) yang dihitung dengan rumus sebagai berikut: VIF $=1 /$ Tolerence

Jika VIF lebih besar dari 10, maka antara variabel bebas (independent variable) terjadi persoalan multikolinearitas (Imam Ghozali, 2001).

Terlihat untuk ketiga variabel bebas, tidak ada satupun variabel bebas yang memiliki besaran VIF lebih dari 10. Selain itu nilai toleransi untuk tiga variabel bebas juga semuanya mendekati angka 1 . Sehingga dapat disimpulkan tidak terjadi adanya multikolonieritas antar variabel bebas dalam model regresi ini.

\section{Uji Heteroskedasitas dan Autokorelasi}

Uji heteroskedastisitas dalam penelitian ini menggunakan uji Glejser. Uji ini dilakukan dengan meregres nilai absolute residual terhadap variabel independen. Jika variabel independen signifikan secara stastistik mempengaruhi variabel dependen (absolute residual), maka ada indikasi terjadi Heteroskedastisitas.

Model regresi yang baik adalah yang homoskedastisitas atau tidak terjadi heteroskedasitas. Deteksi ada tidaknya problem heteroskedasitas adalah dengan media scatterpolt, apabila grafik membentuk pola khusus maka model terjadi heteroskedasitas. Tetapi jika ada pola yang jelas, serta titik - titik menyebar si atas dan di bawah angka 0 pada sumbu Y, maka tidak terjadi heteroskedasitas.

Autokorelasi sering dikenal dengan nama korelasi serial dan sering ditemukan pada data serial waktu (time series). Uji autokorelasi bertujuan menguji apakah dalam model regresi ada korelasi antara kesalahan penggunaan pada periode $t$ dengan kesalahan penggunaan pada periode $\mathrm{t}-1$ (sebelumnya). Model regresi yang baik adalah regresi yang bebas dari autokorelasi. Alat ukur yang digunakan untuk mendeteksi adanya autokorelasi 
Tabel 1

Model Summary ${ }^{b}$

\begin{tabular}{|l|r|r|r|r|c|}
\hline Model & R & R Square & $\begin{array}{c}\text { Adjusted } \\
\text { R Square }\end{array}$ & $\begin{array}{c}\text { Std. Error of } \\
\text { the Estimate }\end{array}$ & $\begin{array}{c}\text { Durbin- } \\
\text { Watson }\end{array}$ \\
\hline 1 & $.721^{\mathrm{a}}$ & .520 & .487 & .12342 & 1.764 \\
\hline
\end{tabular}

a. Predictors: (Constant), ITR, ROA, ATR

b. Dependent Variable: EBIT

Tabel 2

Hasil Uji T

\begin{tabular}{|c|c|c|c|c|c|c|c|}
\hline \multirow{2}{*}{ Variable } & \multicolumn{3}{|c|}{ Bobot pengaruh } & \multicolumn{3}{|c|}{$\begin{array}{l}\text { Signifikansi } \\
\alpha=0,05\end{array}$} & \multirow{2}{*}{ Keterangan } \\
\hline & T hitung & $>1<$ & $T$ table & Pvalue & $>1<$ & sig & \\
\hline \multirow{2}{*}{$\begin{array}{ll}\text { Asset } & \text { turn } \\
\text { gver } & \\
\text { Return on } \\
\text { asset }\end{array}$} & 2,140 & $>$ & 1,6630 & 0,000 & $<$ & 0,05 & H1 diterima \\
\hline & 2,875 & $>$ & 1,6630 & 0,000 & $<$ & 0,05 & H2 diterima \\
\hline $\begin{array}{l}\text { Inventory } \\
\text { turn over }\end{array}$ & 2,285 & $>$ & 1,6630 & 0,000 & $<$ & 0,05 & H3 diterima \\
\hline
\end{tabular}

Sumber: output data spss diolah 2016

dalam penelitian ini menggunakan Tes Durbin Watson (D-W). Uji Durbin Waston hanya digunakan untuk autokorelasi tingkat satu (first order autocorrelation) dan mensyaratkan adanya intercept (konstanta) dalam model regresi dan tidak ada variabel lag di antara variabel independen. Hasil uji autokorelasi ini dapat dilihat pada tabel 1.

Hasil uji menggunakan Durbin-Watson pada model regresi menunjukkan besarnya nilai Durbin-Watson adalah 1,764. Untuk menentukan ada atau tidaknya autokorelasi positif atau negatif pada model digunakan rumus sebagai berikut :

Dimana :

du : Batas atas dari Tabel Durbin-Watson pada $\mathrm{N}=48$ dan $\mathrm{K}=3$

d : Besarnya Nilai Durbin-Watson

maka dapat dihitung sebagai berikut :

$$
\mathrm{du}<\mathrm{d}<3-\mathrm{du}
$$

$1,116<1,764<3-1,116$

$1,116<1,764<1,879$

Berdasarkan perhitungan tersebut dapat disimpulkan bahwa tidak ada autokorelasi positif dan negatif pada model regresi.

\section{Analisis Regresi Linier Berganda Uji Signifikansi Parameter Individual (Uji statistik t)}

Uji ini digunakan untuk menentukan analisis pengaruh asset turn over, return on asset dan inventory turn over terhadap laba pada perusahaan yang terdaftar di BEI tahun 2010-2012. Hasil uji secara parsial dapat terlihat dari Tabel 4.4 berikut ini :

Variabel ATR (X1) mempunyai t hitung sebesar 2,140 dengan signifikansi sebesar 0,000 . Nilai signifikansi t ATR $<0,05$ maka dapat disimpulkan ATR berpengaruh terhadap laba sehingga hipotesis pertama diterima.

Variabel ROA (X2) mempunyai t hitung sebesar 2,875 dengan signifikansi sebesar 0,000 . Nilai signifikansi t $R O A<0,05$ maka dapat disimpulkan ATR berpengaruh terhadap laba sehingga hipotesis kedua diterima. 
Variabel ITO (X3) mempunyai t hitung sebesar 2,285 dengan signifikansi sebesar 0,000 . Nilai signifikansi $t$ ITO $<0,05$ maka dapat disimpulkan ATR berpengaruh terhadap laba sehingga hipotesis ketiga diterima.

\section{Uji Signifikansi Simultan (Uji Statistik f)}

Pengujian ini bertujuan untuk menguji apakah terdapat pengaruh secara bersamasama antara asset turn over, return on asset dan inventory turn over terhadap laba selama periode $2010-2012$.

Pengujian signifikansi berpengaruh variabel assets turn over, return on aseets dan inventory turn over terhadap laba secara simultan dapat dilihat pada pada tabel 4.5. uji simultan, bahwa nilai $F$ hitung sebesar 15,870 dengan signifikansi sebesar 0,000 . Nilai signifikansi sebesar $0,000<0,05$ menunjukkan bahwa variabel ATR, ROA sebagai rasio pengelolaan aktiva dan ITR sebagai rasio pengelolaan persediaan secara simultan mempunyai pengaruh terhdap laba sehingga hipotesis diterima.

\section{Pengaruh asset turn over terhadap EBIT}

Tabel 3

Hasil perhitungan statistik

\begin{tabular}{ll}
\hline Variabel terikat & EBIT \\
\hline$R$ korelasi & 0,597 \\
R determinasi & 0,289
\end{tabular}

Sumber : data sekunder yang diolah 2016

Besarnya nilai korelasi yang menunjukkan hubungan antara asset turn over terhadap EBIT sebagaimana terlihat pada tabel $3 \mathrm{di}$ atas adalah 0,597 termasuk pada kategori kuat (sugiyono, 2004). Besaran nilai korelasi ini mencerminkan bahwa pengaruh hubungan antara asset turn over terhadap EBIT secara kualitatif dapat dikatakan cukup meningkatkan perubahan EBIT.

Berdasarkan hasil uji statistik (Uji t) yang telah dilakukan menunjukkan bahwa asset turn over berpengaruh terhadap laba perusahaan. Asset Turnover menunjukkan kemampuan dana yang tertanam dalam keseluruhan aktiva berputar dalam suatu periode tertentu atau kemampuan modal yang diinvestasikan untuk menghasilkan "revenue" (Bambang Riyanto, 2008). Diharapkan Assets Turnover akan semakin naik yang berarti pemakaian aktiva lebih efisien (Syafaruddin Alwi, 1993) . Rasio yang tinggi biasanya menunjukkan manajemen yang baik, (Mamduh M.Hanafi \& Abdul Halim, 2003). Semakin besar menunjukkan semakin efisien penggunaan seluruh aktiva perusahaan dalam meningkatkan penjualan. Hasil penelitian ini sejalan dengan hasil penelitian dari Dian Meriewati dan Astuti Yuli Setiani (2005), Epri Ayu Hapsari (2007) yaitu Assets Turnover berpengaruh positif signifikan terhadap pertumbuhan laba.

\section{Pengaruh return on assets terhadap EBIT}

Tabel 4

Hasil perhitungan statistik

\begin{tabular}{ll}
\hline Variabel terikat & EBIT \\
\hline$R$ korelasi & 0,639 \\
$R$ determinasi & 0,376 \\
\hline
\end{tabular}

Sumber: Data sekunder yang diolah 2016

Besarnya nilai korelasi yang menunjukkan hubungan antara return on assets terhadap EBIT sebagaimana terlihat pada tabel 4.6.2. di atas adalah 0,639 termasuk pada kategori kuat (sugiyono, 2004). Besaran nilai korelasi ini mencerminkan bahwa pengaruh hubungan antara return on assets terhadap EBIT secara kualitatif dapat dikatakan cukup meningkatkan perubahan EBIT.

Berdasarkan hasil uji statistik (Uji t) yang telah dilakukan menunjukkan bahwa return on asset berpengaruh terhadap laba perusahaan. Semakin besar perubahan ROA menunjukkan semakin besar fluktuasi kemampuan manajemen dalam menghasilkan laba. Hal ini mempengaruhi investor dalam memprediksi laba dan memprediksi risiko dalam investasi sehingga memberikan dampak pada kepercayaan investor terhadap perusahaan. Sehubungan 
dengan itu, manajemen termotivasi untuk melakukan manajemen laba, agar laba yang dilaporkan tidak berfluktuatif sehingga dapat meningkatkan kepercayaan investor. (Budiasih, 2009). Hasil penelitian ini sejalan dengan penelitian Widyastuti (2009) yang menemukan hasil bahwa variabel profitabilitas yang di ukur dengan rasio return on asset (ROA) berpengaruh positif pada laba. Penelitian Dewi dan prasentiono (2012) juga menemukan pengaruh positif dari profitabilitas..

\section{Pengaruh Inventory Turn Over terhadap EBIT}

Tabel 5

Hasil perhitungan statistik

\begin{tabular}{|l|l|}
\hline Variabel terikat & EBIT \\
\hline$R$ korelasi & 0,874 \\
\hline$R$ determinasi & 0,255 \\
\hline
\end{tabular}

Sumber: Data sekunder yang diolah 2016

Besarnya nilai korelasi yang menunjukkan hubungan antara inventory turn over terhadap EBIT sebagaimana terlihat pada tabel 4.6.3. di atas adalah 0,874 termasuk pada kategori kuat (sugiyono, 2004). Besaran nilai korelasi ini mencerminkan bahwa pengaruh hubungan antara inventory turn over terhadap EBIT secara kualitatif dapat dikatakan cukup meningkatkan perubahan EBIT.

Berdasarkan hasil uji statistik (Uji t) yang telah dilakukan menunjukkan bahwa inventory turn over berpengaruh terhadap laba perusahaan. Menurut Munawir (dalam Nina Sufiana dan Ketut Purnawati, 2013) menyatakan bahwa semakin tinggi tingkat perputaran persediaan akan memperkecil resiko terhadap kerugian yang disebabkan karena penurunan harga atau karena perubahan selera konsumen, disamping itu akan menghemat ongkos penyimpanan dan pemeliharaan terhadap persediaan tersebut.

Penelitian yang mendukung teori ini adalah Irman Deni (2012) yang menyatakan perputaran persediaan berpengaruh positif dan signifikan terhadap profitabilitas.Nina Sufiana dan Ni Ketut Purnawati (2013), dalam hipotesis penelitiannya membuktikan secara empiris bahwa perputaran persediaan berpengaruh positif terhadap profitabilitas. .Dari teori yang telah diungkapkan pada hipotesis yang pertama, bahwa semakin tinggi tingkat perputaran persediaan dapat memperkecil resiko kerugian akibat perubahan harga dan perubahan selera konsumen. Hasil penelitian ini sejalan dengan hasil penelitian sebelumnya yang telah dilakukan oleh Irman Deny (2012) dan Nina Sufiana (2013) yang menyatakan bahwa perputaran persediaan berpengaruh positif signifikan terhadap profitabilitas.

\section{Uji Regresi Linier Berganda}

Regresi linier berganda ingin menguji pengaruh dua atau lebih variabel independen terhadap satu variabel dependen (Ghozali, 2009) yang dinyatakan sebagai berikut:

EBIT $Y=a+b 1 X 1+b 2 X 2+b 3 X 3+$ error

$Y=0,027+0,018$ ATR + 0,022 ROA + 0,07 ITR

Keterangan $: \mathrm{Y}=\mathrm{EBIT} / \mathrm{LABA}$ perusahaan

a $\quad=$ konstanta

$\mathrm{b} 1, \mathrm{~b} 2, \mathrm{~b} 3 \quad=$ koefisien regresi

$\mathrm{X} 1 \quad=$ Asset turn over (ATR)

$\mathrm{X} 2 \quad=$ Return on asset (ROA)

$\mathrm{X} 3 \quad=$ Rasio perputaran

persediaan (ITR)

Untuk mengetahui pengaruh variabel dependen yaitu return saham terhadap variabel independen yaitu current ratio, inventory turn over, dan debt to equity ratio pengolahan data dilakukan dengan menggunakan bantuan Software SPSS 17. Hasil yang diperoleh selanjutnya akan diuji kemaknaan model tersebut secara simultan dan secara parsial. Berdasarkan data diperoleh hasil regresi linier berganda sebagai berikut:

Koefisien - koefisien persamaan regresi linier berganda pada tabel 4.7. dapat diartikan sebagai berikut :

Konstanta $(\alpha)$ sebesar $-0,027$ mempunyai arti apabila semua variabel independen 


\section{Tabel 6}

Hasil Analisis Regresi

\begin{tabular}{|c|c|c|c|c|c|}
\hline \multirow[t]{2}{*}{ Model } & \multicolumn{2}{|c|}{$\begin{array}{l}\text { Unstandardized } \\
\text { Coefficient }\end{array}$} & \multicolumn{2}{|c|}{$\begin{array}{l}\text { Standardized } \\
\text { coefficient }\end{array}$} & \multirow[b]{2}{*}{ sig } \\
\hline & $\mathrm{B}$ & Std. error & Beta & $\mathrm{t}$ & \\
\hline (constant) & $-0,027$ & ,029 & & -929 & 358 \\
\hline Asset Turn Over & 0,018 & ,009 & ,289 & 2,140 & 0,038 \\
\hline Return On Asset & 0,022 & ,008 & ,376 & 2,875 & 0,006 \\
\hline Inventory Turn Over & 0,007 & ,003 & ,255 & 2,285 & 0,27 \\
\hline
\end{tabular}

Sumber : data sekunder yang diolah 2016

sama dengan nol maka laba pada saham perusahaan makanan dan minuman bernilai sebesar $-0,027$.

Koefisien regresi ATR sebesar 0,018 artinya setiap kenaikan rasio ATR sebesar 1 satuan menaikkan laba sebesar 0,018 dengan asumsi faktor - faktor yang lain tetap atau cateris paribus.

Koefisien regresi ROA sebesar 0,022 artinya setiap kenaikan rasio ROA sebesar 1 satuan menaikkan laba sebesar 0,022 dengan asumsi faktor - faktor yang lain tetap atau cateris paribus.

Koefisien regresi ITO sebesar 0,007 artinya setiap kenaikan ITO sebesar 1 satuan menaikkan laba sebesar 0,07 dengan asumsi faktor - faktor yang lain tetap atau cateris paribus.

\section{SIMPULAN}

Berdasarkan hasil analisis yang diuraikan sebelumnya, maka dapat di ambil kesimpulan dari variabel independen asset turn over, return on asset dan inventory turn over secara parsial mempunyai pengaruh positif dan signifikan terhadap Ebit atau laba. Hal tersebut membuktikan penelitian penelitian sebelumnya bahwa pengelolaan atas aktiva dan persediaan mempengaruhi laba sebelum pajak (EBIT). Dari analisis tersebut ATR, ROA dan ITO memiliki pengaruh terhadap Ebit atau laba. Sehingga para pemilik perusahaan disarankan untuk menjaga ATR, ROA, dan ITR agar senantiasa tinggi untuk mendapatkan keuntungan yang lebih tinggi.

Dalam penelitian ini terdapat beberapa hal yang menjadi keterbatasan sehingga menurut peneliti mempengaruhi hasil penelitian. Oleh sebab itu peneliti memberikan saran:

Penambahan variabel selain rasio asset turn over, return on asset dan inventory turn over. Perspektif laba sebelum pajak (EBIT) Pada perspektif ini bisa mungkin ditinjau dari perspektif lain semisal perspektif efisiensi laba sesudah pajak (EBIT), Jangka waktu penelitian yang lebih lama semisal 5 tahun dengan jumlah perusahaan yang lebih banyak.

Keterbatasan dalam penelitian ini adalah penelitian ini hanya mengunakan variabel struktur kepemilikan yang mempengaruhi variabel nilai perusahaan sehingga besarnya nilai Adjusted $R$ Square masih sangat kecil, yaitu sebesar 0,487 atau sebesar 48,7 persen, sehingga masih ada sebesar 51,3 persen yang dipengaruhi oleh variabel lain yang belum digunakan dalam penelitian ini.

Berdasarkan keterbatasan penelititan ini, maka untuk penelitian selanjutnya disarankan untuk menambahkan variabel quick ratio agar nilai Adjusted $R$ Square bernilai lebih besar dari sebelumnya. Hal ini juga bertujuan agar kesimpulan yang dihasilkan nanti memiliki cakupan yang lebih luas mengenai struktur kepemilikan. 


\section{DAFTAR PUSTAKA}

Aref Mahdavi, Nejat Younesi, Mohammad Hashemijo, 2012. " acquisition, earning management, and agent performance". Journal of business studies quarterly, vol. 4 no. 1, pp. 91 -110.

Birham and Eugene, 1983. "Fundamental Of Financial Management". The Dryden press: Holt - Sounders japan, Third edition.

I G A N Budiasih. 2009."Faktor - faktor yang mempengaruhi perataan laba," jurnal ilmiah akuntansi dan bisnis, vo.4 no. 1 januari 2009.

Epri Ayu Hapsari, 2007, Analisis Rasio Keuangan untuk Memprediksi Pertumbuhan laba (Studi Kasus Perusahaan Manufaktur yang Terdaftar di Bursa Efek Jakarta Periode 2002 sampai dengan 2005), Tesis Program Pasca Sarjana Magister Manajamen Universitas Diponegoro (tidak dipublikasikan)

Gujarati, Damodar, 1995. "Basic Econometrics" alih bahasa sumarno zain, ekonometrika dasar, penerbit erlangga, Jakarta

Imam Ghozali, 2005. Aplikasi analisis Multivariate dengan program SPSS, Semarang: BP UNDIP.

Indonesian capital market directory 2010

Indonesian capital market directory 2011

Indonesian capital market directory 2012

Iskandar Rusli, 2009. "Pengaruh Asset Dan Manajemen Inventory Terhadap Manajemen Laba”. Bisnis dan birokrasi, jurnal ilmu administrasi dan organisasi, sep - des. 160 - 169.

Kasmir.2011. Analisis Laporan Keuangan. Cetakan keempat. Jakarta : Rajawali Pers

Gunawan, I Ketut, Darmawan, Nyoman Ari Surya dan Purnamawati, I Gusti Ayu. 2015. Pengaruh Ukuran Perusahaan, Profitabilitas, dan Leverage Terhadap Manajemen Laba pada Perusahaan Manufaktur Yang Terdaftar Di Busa Efek Indonesia (BEI), jounal S1 Ak, Universitas Pendidikan Ganesha, Volume 3 No. 1

Meriewaty, Dian dan Astuti Yuli Setyani, 2005, "Analisis Rasio Keuangan terhadap Perubahan Kinerja pada Perusahaan di Industri Food and Beverages yang terdaftar di BEJ", Jurnal Riset Akuntansi dan Keuangan, Vol.1 No. 2, Agustus

Setiyanto, Muchamad Danu dan Rahardja. 2012. Pengaruh Mekanisme Corporate Governance terhadap Manajemen Laba dan Pengaruhnya terhadap Kinerja Perusahaan pada Perusahaan Manufaktur yang Terdaftar di BEI. Diponegoro Journal of Accounting. 1(1): 1-15.

Shimin, Chen., Yuetang Wang, Ziye Zhao. 2009. Regulatory Incentives for Earnings Management Through Asset Impairment Reversals in China. Journal of Accounting, Auditing, and Finance. 24(4): 589-620.

Robert Ang, 1997. "Buku Pintar: Pasar Modal Indonesia (The Intelligent guide to Indonesian Capital Market )" Media Soft Indonesia, First Edition. 